\title{
КОГНІТИНО-ДИСКУРСИВНЕ ДОСЛІДЖЕННЯ РОСІЙСЬКОГО СКЛАДНОГО РЕЧЕННЯ
}

\author{
(Палатовская Е. В. Сложное предложение в когнитивно-дис-
} курсивном аспекте. Киев: ПП «Фірма ”Гранмна“», 2019. 400 с.).

Монографія Олени Володимирівни Палатовської присвячена актуальному, недостатньо вивченому в лінгвістиці аспектові когнітивно-дискурсивного дослідження російського складного речення. Цінність обраного авторкою монографії підходу до вивчення цієї синтаксичної одиниці полягає не лише в тому, що він відповідає канонам сучасного антропоцентричного напряму в лінгвістиці, а ще й у тому, що врахування сучасних напрацювань суміжних з лінгвістикою наук дає змогу висунути й обгрунтувати методологійні положення, що відображують реальні процеси сприйняття і породження мови, а не лише теоретично моделюють їх.

О. В. Палатовська сміливо поставила виключно складне та принципово нове для лінгвістичної науки завдання - дослідити й описати співвідношення і взаємодію ментальних та мовних структур з погляду породження і сприйняття складних речень російської мови. Складність поставленого завдання зумовлена невизначеністю в сучасній науці багатьох теоретичних питань у цій галузі, зокрема недостатньою вивченістю лінгвістикою та суміжними науками низки загальних методологійних проблем, пов'язаних з теорією комунікації. Це й проблема прийнятності теорії кодування і декодування, що йде від кібернетики як основи зв'язку між мовними та мисленнєвими одиницями, і пов'язана з нею необхідність відповіді на запитання, чи варто розглядати процес людської комунікації як один з інформаційних, це й проблема статичності та динамічності мовних і мисленнєвих утворень, і проблема розмежування мовних та мисленнєвих структур, яку когнітивна лінгвістика всупереч твердженням окремих учених не знімає, тощо.

У роботі вдало поєднані теоретичний аспект і психолінгвістичний експеримент, що сприяє, з одного боку, верифікації теоретичних положень, а з другого - дає змогу теоретично осмислити отримані експериментально результати. 
Не викликає сумнівів теоретичне й практичне значення проведеного О. В. Палатовською дослідження, що зазначено в монографії, і з цим можна цілком погодитися.

Теоретичним підгрунтям роботи слугують напрацювання представників суміжних наукових дисциплін - лінгвістів, філософів, психолінгвістів і психологів. Реєстр використаної наукової літератури містить понад 400 позицій. Цінними, на нашу думку, є додатки, у яких наведений експериментальний матеріал дослідження.

Слід відзначити високу наукову культуру виконаної праці: відсутність стилістичних огріхів, ретельну паспортизацію цитованого й ілюстративного матеріалу, логічність композиції, продумані переходи від одного розділу до іншого.

Звичайно, коли йдеться про масштабне наукове дослідження, що порушує методологійні питання науки, не може не виникнути певних міркувань, що не збігаються із твердженнями автора монографії та переважно відбивають різні погляди лінгвістів на природу мовних явищ. Важко не погодитися з відомим висловлюванням: «У нас стільки лінгвістик, скільки лінгвістів». Тому те, про що йтиметься далі, слід сприймати не як зауваження, що можуть вплинути на загальну високу оцінку роботи, а як роздуми й запитання, що спонукають до дискусії.

Насамперед окремі запитання, що потребують уточнення, виникли під час знайомства з деякими теоретичними положеннями роботи. У першому розділі «Когнітивна лінгвістика: витоки, проблеми теорії та моделювання мовної діяльності» багато уваги присвячено розгляданню історичного контексту, у якому відбувалося становлення когнітивного підходу до аналізу мовних одиниць у ракурсі проблеми співвідношення мови й думки, зокрема в роботах О. О. Потебні. При цьому О. В. Палатовська не ставить завдання створити власну загальну когнітивну теорію. У цьому разі вважаємо, що доцільнішим було 6 в експліцитній формі постійно підкреслювати зв'язок положень, що аналізуються, $з$ когнітивно-дискурсивним вивченням складного речення.

Про концепцію О. О. Потебні написано чимало лінгвістичних праць, і в першому розділі монографії принципово нові аспекти концепції вченого не розглядаються. Крім того, в описі поглядів О. О. Потебні інколи фіксуємо прямо протилежні твердження, які 
в монографії недостатньо прокоментовано. Зокрема, О. В. Палатовська пише: «Отже, на думку О. О. Потебні <...>, ні мислення, ні мова не становлять самостійних модулів, вони тісно взаємопов'язані й узгоджено взаємодіють у складних когнітивних процесах опрацювання, зберігання та передавання інформації» (Палатовская, 2019: 25). Далі читаємо: «О. О. Потебня стверджує, що «думка існує незалежно від мови» (Палатовская, 2019: 27), що, на погляд авторки дисертації, цілком узгоджується із сучасними уявленнями про паралельне функціонування вербального й невербального мислення. У теорії паралельного функціонування вербального й невербального мислення багато незрозумілого. Не викликає сумніву те, що вербальні образи можуть брати участь у процесі мислення, але, мабуть, не як самостійні мовні утворення, а як одиниці, що асоціюються 3 «предметними» образами, оперування якими визначає сутність мислення. Тобто вербальне мислення в «чистому вигляді» навряд чи існує.

Незрозуміло, як «передавання інформації», про яке пише авторка (див. вище коментар до цитати О. О. Потебні), узгоджується з таким положенням О. О. Потебні: «...при розумінні думки́ мовця не передаються, але слухач, розуміючи, створює свою думку. <...> ... тому розуміння в сенсі тотожності ду́мки мовця і слухача $є$ ілюзією, у якій дійсною виявляється тільки певна подібність, аналогічність між ними, що пояснюється схожістю інших сторін людської природи» (Палатовская, 2019: 25-26).

Не впевнений у тому, що потребує особливих доказів положення про те, що в протиставленні усного й писемного модусів науково-професійного дискурсу усний спонтанний дискурс $є$ первинним. Мабуть, це $є$ проявом загальної закономірності, згідно з якою писемний модус дискурсу вторинний щодо усного в аспекті породження і смислового сприйняття. Про це, посилаючись на праці А. О. Кибрика, пише сама О. В. Палатовська: «Усне мовлення первинне як на філогенетичному рівні, так і на онтогенетичному» (Палатовская, 2019: 28). До речі, можливий варіант, коли в усному науковому дискурсі (наприклад, у виступі на конференції) відчувається вплив заздалегідь написаної письмової форми доповіді, але це вже за інших комунікативних умов.

Незважаючи на висловлювання авторитетних учених (наприклад, О. А. Земської), я 6 не поспішав розлучатися з поняттям «мовлення» в тріаді «мова - мовлення - мовленнєва діяльність». По-перше, 
використання метафор, у цьому разі й комп’ютерних, не завжди $є$ корисним в науці про мову, що й без того занадто заметафоризована. По-друге, заміна терміна «мовлення» терміном «мова онлайн» суттєво не змінює зміст відповідного поняття, а повна аналогія процесів людської комунікації та передачі інформації кібернетичними системами дещо сумнівна.

Важко погодитися з тим, що складне речення розчленовано репрезентує зв'язки та відношення між ситуаціями довкілля. Здається, що більш коректно розглядати цей зв'язок як опосередкований одиницями мислення, що не є механічним відображенням ситуацій дійсності.

Говорячи про становлення антропоцентричного напряму, доречно було б згадати бібліопсихологію М. О. Рубакіна, зокрема його книгу «Психологія читача та книги». Серед робіт, присвячених розрізненню мови, мовлення та мовленнєвої діяльності, не названо відому книгу О. О. Леонтьєва «Мова, мовлення, мовленнєва діяльність», перевидану в 2019 році.

У другому розділі монографії «Складне речення в контексті зміни наукових парадигм» ідеться про вивчення складного речення в контексті різних лінгвістичних парадигм. Авторка подає онтологічні вектори, ключові підходи до дослідження мовних об’єктів, що відповідають певній науковій парадигмі. У цій частині дослідження розглянуті базові питання теорії складного речення. Важливо, що дослідниця ретельно аналізує кожну теорію, висловлюючи власне ставлення до неї. У розділі чітко визначено когнітивно-дискурсивний статус складного речення.

I все ж таки варіативність підходів до аналізу мовного матеріалу не завжди дає змогу авторці зберегти методологійну єдність оцінок теорій, що розглядаються. Зокрема, відокремлюючи текст від дискурсу, О. В. Палатовська посилається на О. С. Кубрякову й пише, що текст має однозначний зміст, на відміну від багатозначного змісту дискурсу. Але, якщо прийняти підхід О. О. Потебні, на що було наголошено в першому розділі, зміст з'являється в тексті лише тоді, коли він «занурений у життя», за відомим висловлюванням Н. Д. Арутюнової, тобто перетворився на дискурс. Текст поза процесом комунікації, з огляду на цю теорію, взагалі позбавлений змісту. Розглядати текст поза процесом комунікації як змістовне утворення можливо 
лише з позиції кодування в ньому певної інформації, тобто в межах іншої парадигми.

Висловлені зауваження зумовлені передусім складністю поставлених у роботі завдань та багатовекторністю підходів до їхнього розв’язання, дотичні лише способу репрезентації деяких положень дисертації та не ставлять під сумнів цілісність і повноту концепції дослідження, що повною мірою відображені в монографії О. В. Палатовської.

У третьому розділі «Складне речення в усній науково-професійній комунікації: породження і сприйняття» схарактеризовано усне складне речення з урахуванням когнітивної позиції адресата (слухача) й адресанта (мовця). Авторка визначає когнітивні стратегії членування дискурсу на синтаксичні одиниці в режимі онлайн, установлено дискурсивний статус речення як проміжної одиниці дискурсу й ступінь стійкості синтаксичних зв'язків у складному реченні, з'ясовано основні способи трансформації усного складного речення в писемну форму. О. В. Палатовська глибоко досліджує процеси породження наукового монологу, релевантні для складного речення; описує основні структурно-семантичні моделі складних речень і найчастотніші засоби зв'язку їхніх компонентів.

Ретельний аналіз результатів експериментального дослідження синтаксису мінілекцій, що було проведено за онлайн- і офлайн-методиками, дає підстави для важливого висновку про те, що усний науково-професійний дискурс посідає проміжне місце між розмовною мовою і кодифікованим типом літературної мови, зазнаючи їхнього одночасного впливу.

Цінність четвертого розділу «Російське складне речення в аспекті теорії прототипів: когнітивні інваріанти й механізми їхньої актуалізації в спонтанній комунікації» зумовлена тим, що авторці вдалося переконливо довести, що в свідомості носіїв мови існують певні зв’язки між ментальною репрезентацією конкретної типової ситуації або комплексу ситуацій і синтаксичними конструкціями, що об'єктивують семантико-синтаксичний інваріант у вербальному висловлюванні. Запроваджене експериментальне дослідження уможливило визначення реєстру прототипних засобів зв'язку, що маркують ті чи ті семантико-синтаксичні відношення між частинами складного речення, а також установити співвідношення між формальною 
організацією прототипної синтаксичної конструкції та відповідним типом дискурсу. Оригінальна авторська методика, статистичне опрацювання результатів експерименту й звернення до матеріалів Національного корпусу російської мови забезпечили достовірність висновків у цьому розділі роботи та дали змогу підтвердити гіпотезу, заявлену на початку дослідження, про те, що в усному модусі наукового дискурсу асиметрія щодо виборів засобів зв'язку між частинами складного речення, характерна для нейтрального й наукового мовлення, нейтралізується, тому що мовець витрачає когнітивні зусилля передусім на зміст висловлювання, інтуїтивно актуалізуючи з активності свідомості прототипні сполучникові одиниці.

Отже, мету, поставлену в роботі О. В. Палатовської, досягнуто, сформульовані завдання цілком виконано.

Рецензована монографія - значний крок уперед у когнітивнодискурсивному вивченні мовних одиниць, зокрема складних речень російської мови, методологія та методика аналізу яких може бути з успіхом екстрапольована на дослідження інших мовних одиниць. Висновки, яких дійшла авторка, нові, цілком логічні, обгрунтовані аналізом великого за обсягом мовного матеріалу.

Підсумовуючи, зазначимо, що теоретичні узагальнення, отримані експериментально результати, запропонована методика опрацювання фактичного матеріалу й висновки роботи відзначаються науковою новизною, глибиною і достовірністю та слугуватимуть теоретичним і практичним підгрунтям для нових когнітивно-дискурсивних студій з вивчення як складного речення, так й інших мовних одиниць. Безсумнівне й практичне значення дослідження, що передбачає використання його матеріалів під час викладання синтаксису, загального мовознавства, спецкурсів з когнітивної лінгвістики, психолінгвістики, практичного курсу російської мови для іноземних громадян, у написанні підручників та практичних граматик тощо.

\section{ЛІТЕРАТУРА}

1. Палатовская, Е. В. (2019). Сложное предложение в когнитивно-дискурсивном аспекте. Киев: ПП «Фірма ”Гранмна“».

\section{REFERENCES}

1. Palatovska, E. V. (2019). Slozhnoe predlozhenie v kognitivno-diskursivnom aspekte [Complex sentence in cognitive-discursive aspect]. Kiev: PP «Firma "Granmna"» [in Russian]. 
Степанченко Іван Іванович - доктор філологічних наук, професор, професор кафедри зарубіжної літератури та слов'янських мов; Харківський національний педагогічний університет імені Г. С. Сковороди; вул. Валентинівська, 2, Харків, 61168, Україна; професор кафедри російської мови; Харківський національний університет імені В. Н. Каразіна; площа Свободи, 4, м. Харків, 61022, Україна.

Тел.: +38068-6108902; (057) 702-38-85

E-mail: istepanchenko@ukr.net

https://orcid.org/0000-0002-9983- 2012

Stepanchenko Ivan Ivanovych - Doctor of Philological Sciences, Professor, Professor at the Department of Foreign Literature and Slavonic Languages, H. S. Skovoroda Kharkiv National Pedagogical University; Valentynivska Str. 2, Kharkiv, 61168, Ukraine; Professor at the Department of Russian Language, V. N. Karazin Kharkiv National University; Svoboda Sqr. 4, Kharkiv, 61000, Ukraine.

Надійшла до редакції 26 вересня 2020 року

\section{CITATION}

ДСТУ 8302:2015: Степанченко I. І. Когнітивно-дискурсивне дослідження російського складного речення. Рец. на моногр.: Палатовская Е. В. Сложное предложение в когнитивно-дискурсивном аспекте. Киев: ПП «Фірма ”Гранмна“», 2019. 400 с. Лінгвістичні дослідження: зб. наук. пр. Харк. нац. пед. ун-ту імені Г. С. Сковороди. Харків, 2020. Вип. 53. С. 276-282. DOI: https://doi.org/10.34142/23127546.2020.53.26

APA: Степанченко, I. I. (2020). Когнітивно-дискурсивне дослідження російського складного речення. Рец. на моногр.: Палатовская Е. В. Сложное предложение в когнитивно-дискурсивном аспекте. Киев: ПП «Фірма ”Гранмна“», 2019. 400 с. Лінгвістичні дослідження, 53, 276-282. DOI: https://doi.org/10.34142/23127546.2020.53.26 